\title{
Neurotoxic effect of spinetoram on Spodoptera littoralis (Boisd.) Larvae
}

\section{Laila, S. Hamouda ${ }^{1}$ and Hassan F. Dahi ${ }^{2}$}

1-Department of Entomology, Faculty of Science, Ain Shams Univ., Cairo, Egypt. 2-Plant Protec. Res. Instit., Agric. Res. Center, El Dokki, Giza, Egypt.

\section{ABSTRACT}

The present study was conducted to evaluate the neurotoxic effect of spinetoram on Spodoptera littoralis (Boisd.) larvae. Testing different concentrations of this green chemical compound against $4^{\text {th }}$ instar larvae showed that spinetoram is a fairly toxic with $\mathrm{LC}_{50}(1.11 \mathrm{ppm})$. Its neurotoxicity was manifested as evident histopathological changes in the structure of neurosecretory (NSCs) and ordinary nerve cells (NCs) of suboesophageal ganglion (SOG) of this pest after treatment with $\mathrm{LC}_{50}$ of this compound.

Photo and electron micrographs of suboesophageal ganglion (SOG) of treated S.littoralis larvae with $\mathrm{LC}_{50}$ of spinetoram showed aggregation of neurosecretory granules in the oval, triangle and irregular shaped neurosecretory cells but not in the round shaped cells. Also, the SOG of treated larvae showed an apparent vacuolization and increase in the size of cytoplasm, abundance and aggregation of mitochondria in nerve cells and all kinds of NSCs (round, irregular, triangle and oval) and the appearance of multivesicular bodies in the cytoplasm of neurosecretory cells.

Keywords: Spodoptera littoralis - Spinetoram - Suboesophageal Ganglion, Ultrastructure - Neurosecretion.

\section{INTRODUCTION}

The Egyptian cotton leafworm, S. littoralis (Boisd.) (Noctuidae: Lepidoptera) is an economically important pest with a wide range of host plants. This species has acquired resistance to many insecticides (Hassanein ,1999). The increased use of several groups of chemical pesticides to control this insect has led to environmental pollution causing danger to all organisms including man. It is important to use alternative methods for the control of crop pests. The use of Green chemicals, have the advantages of being pest selective and environment friendly.

Spinetoram is a new member of the spinosyn class of insect management tools developed by Dow Agrosciences company. It is derived from fermentation of Saccharopolyspora spinosa as are other spinosyns, but fermentation is followed by chemical modification to create the unique active ingredient in spinetoram. It provides long lasting control of a broad spectrum of insect pests in a variety of crops. It is applied at low rates and has low impact on most beneficial insects (Mertz and Yao, 1990).

Pests controlled by spinetoram include beet army worm, Spodoptera exigua, thrips, Frankliniella spp., cabbage looper, Trichoplusia ni and codling moth, Cydia pomonella (Crouse and Sparks, 1998).

Spinetoram causes excitation of the insect nervous system by altering the function of nicotine and GABA-gated ion channels. It dose not interact with the 
known binding sites of other classes of insecticides such as of neonicitinoids, fiproles or avermectins (Crouse and Sparks, 1998).

The sub-oesophageal ganglion of insects comprises the fused ganglia of the primitive mandibular, maxillary and labial segments or neuromerers (Altman and Kien, 1987). It has been reported by (Hasegawa, 1952) a source of a hormone which is released into the maternal circulation causing diapause of the newly laid eggs of the silk worm. In leucophaea maderae, Scharrer (1955) suggested an endocrine link between the gonads and a pair of neurosecretory cells in the sub-oesophageal ganglion on the basis of changes in these cells following ovariectomy.

Accounts of neurosecretory cells in the ventral ganglia of insects are very rare in comparison with the numerous descriptions which exist of such cells in insect brains (Raabe ,1982). They were noticed in the ventral ganglia of some insects including lepidopteran species such as Bombyx mori (Fukuda and Takeuchi, 1967 b) and Antheraea mylitta (Tripathi and Arif, 2005).

The present work is designed to evaluate the toxicity of one of the green chemical compounds, spinetoram to S. littoralis (Boisd.) larvae. Also, to study the hisotopathological changes in the structure of neurosecretory and nerve cells of the sub-oesophageal ganglion of $S$. littloralis larvae after treatment with $\mathrm{LC}_{50}$ of this compound.

\section{MATERIALS AND METHODS}

The original colony of the cotton leaf worm, S.littoralis (Boisd.) [Lepidoptera: Noctuidae] was obtained from a well-established culture, maintained at the Cotton leafworm Department, Plant Protection institute. Insect rearing was conducted in the laboratory as described by Dahi (1997).

\section{Tested Compound:-}

Spinetoram.

Trade name:

Radiant (12\% SC).

\section{Chemical name:}

This compound is a mixture of major and minor components:

Major component (3'-ethoxy-5,6-dihyro spinosyn J).

Minor component (3'-ethoxy spinosyn L).

a) Bioassay of spinetoram on the $4^{\text {th }}$ instar larvae of $S$. littoralis:-

The larvicidal activity of the tested compound was evaluated on newly moulted $4^{\text {th }}$ instar of S. littoralis larvae. Fresh castor oil leaves were immersed in each of the prepared concenterations of the tested compound and then left to dry at room temperature before being offered to the $4^{\text {th }}$ instar larvae confined in glass jars. Larvae were offered contaminated leaves for $24 \mathrm{~h}$. Each treatment comprised 50 larvae and was replicated 5 times. The same numbers of larvae were used as a control. They were offered castor oil leaves immersed in distilled water. Larval mortality was calculated after 24 hrs. and mortality percentages were corrected according to Abbott (1925). Results were presented graphically as log/probit regression lines and $\mathrm{LC}_{50}$ value calculated by the computer program Sigma Plots for Windows (version 2).

\section{b) Electron microscopic studies:}

The dissected suboesophageal ganglion of untreated $4^{\text {th }}$ larval instar of S.littoralis and those treated with $\mathrm{LC}_{50}$ of spinetoram were fixed immediately in fresh cold glutraldehyde for 2 hours, washed 3 times in buffer (for 3 minutes each time). They were post fixed in $1 \%$ osmic acid at $4^{\circ} \mathrm{C}$ for 2 hours and washed twice in buffer 
for 15 minutes each time. Dehydration was carried out in ascending grades of alcohol from $50 \%$ to $100 \%$. The blocks were cut on Reichert Jug ultra-microtome. Semi-thin and ultra-thin sections of $0.5-1.0 \mathrm{~m}$ and $60-20 \mathrm{~nm}$ thickness, respectively, were cut. Semi-thin sections were stained for 1-2 minutes in toluidine blue solution and examined by light microscope. The ultra-thin sections were stained with $2 \%$ uranyl acetate for 15 minutes and lead citrate for 3 minutes and examined. Examination of stained sections was carried out by transmission electron microscope at the central lab of Ain Shams University.

\section{RESULTS AND DISCUSSION}

\section{Toxicological studies:}

A range of concentrations was prepared from spinetoram and preparations were tested on the $4^{\text {th }}$ instar larvae of S. littoralis. Toxicity was exhibited in a dose dependent phenomenon. From the plotted regression line the $\mathrm{Lc}_{50}$ value of spinetoram was determined as $1.11 \mathrm{ppm}$ with slope 1.96 (Fig.1).

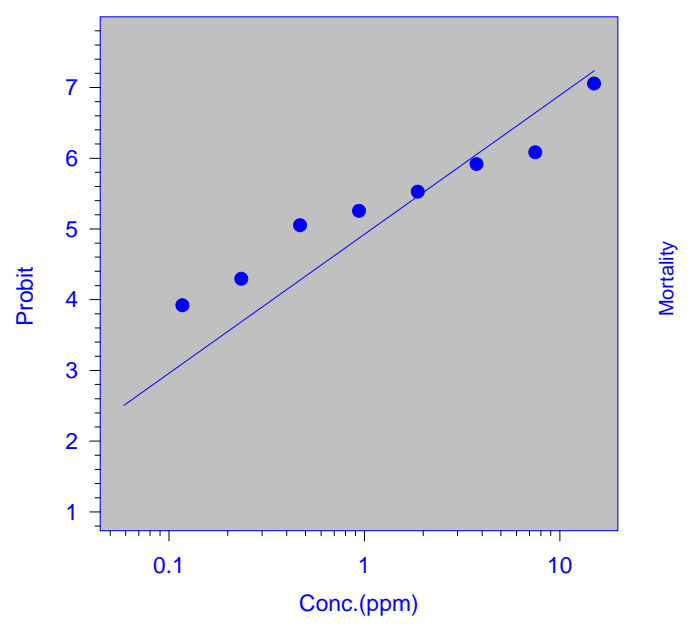

Fig (1): Effect of Spinetoram on $4^{\text {th }}$ instar larvae of Spodoptera littoralis

\section{Histopathological studies:}

Photo micrographs of semithin sections of the suboesophageal ganglion (SOG) of untreated Spodoptera littoralis larvae revealed that the bulk of the SOG consists of a neuropile mass (NPM) which contains certain tracts made up of single or bundles of nerve fibres (NF) as well as there are some trachaea (TR) lying either inside the neuropile mass itself or at its peripheral margins (Fig.2).The whole ganglion is limited by a syncytial sheath, the perineurium which is covered by a layer of compact collagenous sheath forming the neurolamella (NL)(Fig.2).

Neurosecretory (NSCs) and nerve cells (NCs) of SOG are localized in the cortical as well as in the internal regions of the ganglion (Fig.2).The NSCs showed different shapes and intensities of the neurosecretory material (NSM). At the anterior portion of the SOG ganglion (Fig.3), there was a cluster of round cells with round nuclei having plenty of chromatin. Some of these cells have prominent nucleoli at their nuclear membrane. Others have small round nucleus having scanty chromatin. The cytoplasm (CY) of all these cells appeared devoid of neurosecretory granules. On 
the other hand, the posterior portion of SOG exhibited different shapes of NSCs (round, irregular, triangle and oval).The first shape was round cells having round nuclei with scanty chromatin (Fig.4). Other round cells having plenty chromatin and a prominent nucleoli (Fig.4), The second shape was irregular neurosecretory cells having rounded nuclei with plenty chromatin (Fig.5). The third shape was triangleshaped cells having round nuclei rich with chromatin (Fig.5). The last shape was oval cells with oval nuclei rich with chromatin (Fig.4). The neurosecretory granules (NSG) of all the previously mentioned cells were distributed in the entire perikarya of the cells and in triangle-shaped cells; they could be traced up to certain distance in the axon.

These NSCs could be considered in the synthesis phase of cell activity according to Tripathi and Arif (2005) who observed four phases of cell activity in Indian tasar silk worm, Antheraea mylitta, including synthesis, coalescence, release and resting phases. The synthesis phase is characterized by synthesis of neurosecretory granules which were scattered in the entire perikaryon.

In the present study, The round NSCs of SOG of S.littoralis larvae treated with $\mathrm{LC}_{50}$ of spinetoram (Fig.6) showed no evident change in the amount of NSM and the NSGs were scarse as in the untreated larvae. However, oval and triangle-shaped NSCs cells showed accumulation of NSM towards their poles and it appeared as a dense aggregation of large electron dense granules in the oval NSCs (Fig.7). Again, according to Tripathi and Arif (2005) the round NSCs in the treated S.littoralis larvae could be considered in synthesis phase of cell activity, while oval, irregular and triangle shaped cells were in releasing phase or in coinciding synthesis and releasing phases. These findings suggested that production of NSG might have been going on at higher rate than their release from most shapes of NSCs in S.littoralis larvae treated with $\mathrm{Lc}_{50}$ of spinetoram. i.e. spinetoram might have interfered with normal release of NSG leading to their accumulation in oval, triangle and irregular shaped neurosecretory cells(Figs. 11\&14) However, the scarcity of the NSGs in the round NSCs of the untreated and treated larvae may suggest slow production and / or high rate of release of NSG than in other shapes of NSCs. These conclusions are in accordance with findings in normal and diapausing adult and immature insects (Novak, 1966). On the other hand, Highnam (1962) described NSCs with scarcity or devoid of NSG as being active cells that synthesize and release neurosecretory material and as being inactive cells when packed with neurosecrotory material.

The abundance of mitochondria and their accumulation were quite evident in nerve cells and all neurosecretory cells of the treated larvae (Figs. 9, 11\&13) .This may suggest that the cells are involved in an increasing metabolic activity.

Generally, electron micrographs of nerve cells, round, oval and irregular neurosecretory cells of treated S.littoralis larvae with $\mathrm{Lc}_{50}$ of spinetoram (Fig.) showed an apparent increase in the size of the cytoplasm (Figs.9, 10, 11, 13\&14).

Vacuolization was also observed in the nerve cells and all neurosecretory cells of the S.littoralis larvae treated with $\mathrm{Lc}_{50}$ of spinetoram reflecting cell destruction (Figs. 10\&11) Moreover; multivesicular bodies were observed in the cytoplasm of the NSCs of the SOG of the treated larvae in the present study (Fig.15). These bodies are a variety of heterolysosomes that behave as autolysosomes to digest endogenous material such as cell lysis products and secretory granules.

In conclusion, Spinetoram is a fairly toxic compound to the 4th larval instar of Spodoptera littoralis larvae treated with $\operatorname{Lc}_{50}(1.11 \mathrm{ppm})$.It has a neurotoxic effect manifested as well defined histopathologiacal changes in nerve and neurosecretory cells. Also, neurotoxic effects of this compound were manifested as paralysis of some 
Spodoptera littoralis larvae after treatment with low concentrations and lethality at the high concentrations of spinetoram

\section{RERFERNCES}

Abbott, W. S. (1925). A method of computing the effectiveness of an insecticide. J. Econ. Entomol., 18 (2): 256-267.

Altman, J.S. and Kien, J. (1987). Functional organization of the suboesophageal ganglion in arthropods. In: Arthropod Brain: Its Evolution, Development, Structure and Functions. Gupta AP (ed.), Wiley, New York.

Crouse,G.D. and Sparks , T.C.(1998). Naturally derived materials as products lead for insects control : the spinosyns .Rev. Toxicol., 2 : 133-146.

Dahi, H. F. (1997). New approach for management the population of cotton leafworm Spodoptera littoralis (Boisd.) and pink bollworm Pectinophora gossypiella (Saund.) in Egypt. Master Thesis, Fac. Agric. Cairo University, Egypt.

Fukuda, S. and Takeuchi, S. (1967 b). Studies on the diapuse factor producing cells in the sub-osophageal ganglion of the silk worm , Bombyx mori L. Embryol., 9: 333-353.

Grouse, G.D. and Sparks, T.C. (1998). Naturally derived materials as products and leads for insect control. The spinosyns. Rev. Toxicol., 2: 133-146.

Hasegawa, k. (1952). Studies on the voltinism in the silk worm, Bombyx mori L., with special reference to the organs concerning determination of voltinism. J. Fac. Agric. Tottori. Univ. 11: 83-124.

Hassanein, A.A.(1999): Comparative toxicity and tolerance for some insecticides in a laboratory and field strains of cotton leaf worm. Ph.D. Thesis, Fac. Agric.,Cairo University, Egypt.

Highnam, K.C. (1962). Neurosecretory control of ovarian development in the desert locust, Schistocerca gregaria. Quart. J. Micros. Sci., 102: 27-38.

Mertz, F.P. and Yao, R.C. (1990). Sacharo polyspora spinosa sp. Nov. isolated from soil collected in sugar mill rum still. Int. J. Sys. Bacteriol. , 40: 34-39.

Novak,V.J.A. (1966). Insect hormones . Methuen and Coltd

Raabe,M.(1982):Insect neuro hormones. Plenum press ,New York.

Scharrer, B. (1955). 'Castration' cells in the central nervous system of an insect (Leucophaea maderae, Blattaria). Trans. N.Y. Acad. Sci., 17(2): 520-525.

Tripathi, P.N. and Arif, M. (2005). Neuroendocrine organs and neurosecretion in Indian tasar silk worm, Antheraea mylitta D. (Lepidoptera: Saturnüdae). Biochem. Cell Arch. 5(1):37-72. 


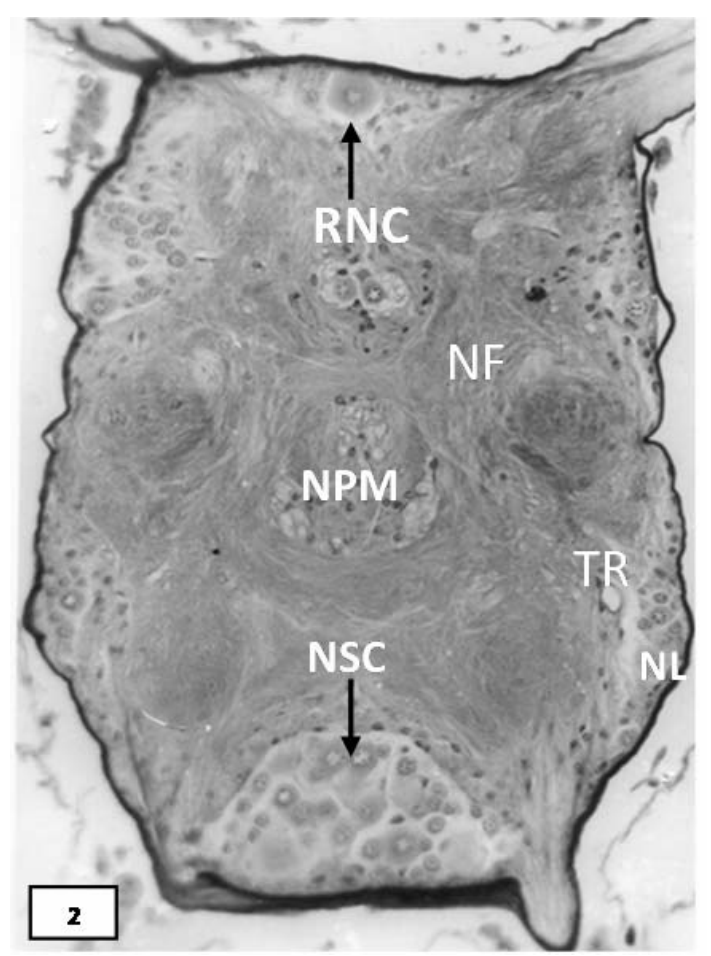

Fig. 2: Showing the structure of the suboesophageal ganglion (SOG). Notice neuropile mass (NPM), neurolamella (NL), neurosecretory cells (NSCs) and round nerve cells (RNCs). $\mathrm{X}: 400$

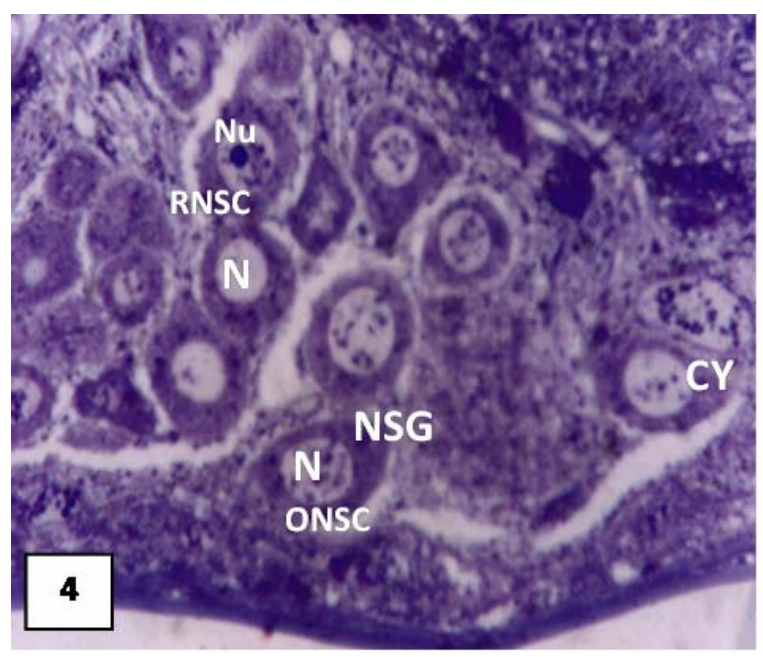

Fig.4: Showing the structure of the round and oval neurosecretory cells (RNSCs and ONSCs) in the posterior portion of suboesophageal ganglion (SOG). Notice the nucleus $(\mathrm{N})$, the nucleoli $(\mathrm{NU})$ and the neurosecretory granules (NSG) in the cytoplasm ( CY). X:400

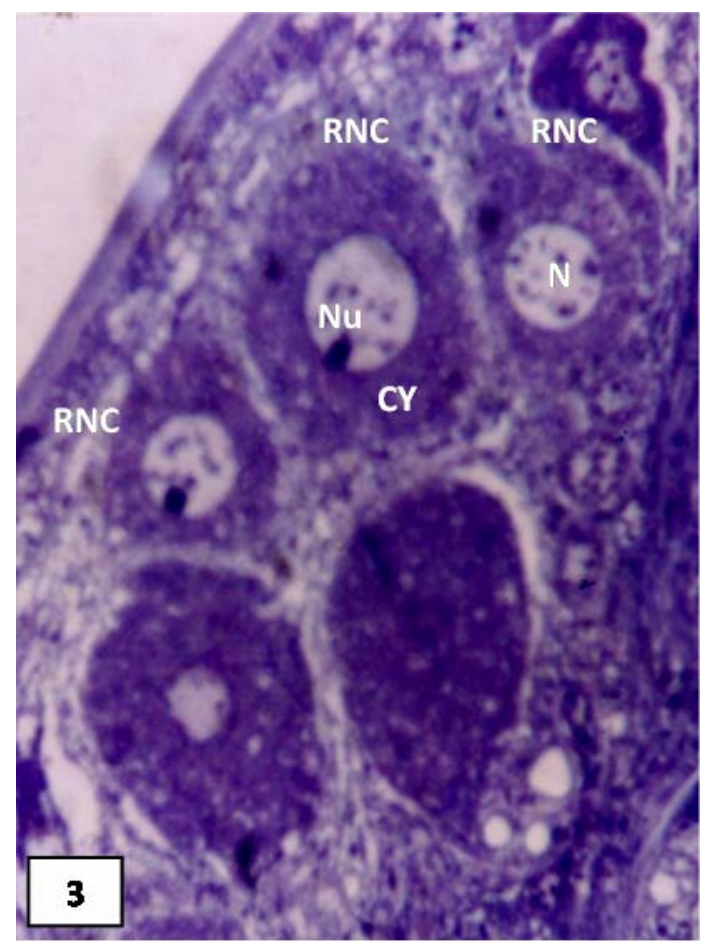

Fig.3: Showing the structure of the round nerve cells (RNCs) in the anterior portion of the suboesophageal ganglion $(\mathrm{SOG})$. Notice the nucleus $(\mathrm{N})$, the nucleoli $(\mathrm{NU})$ and the cytoplasm (CY). X:400

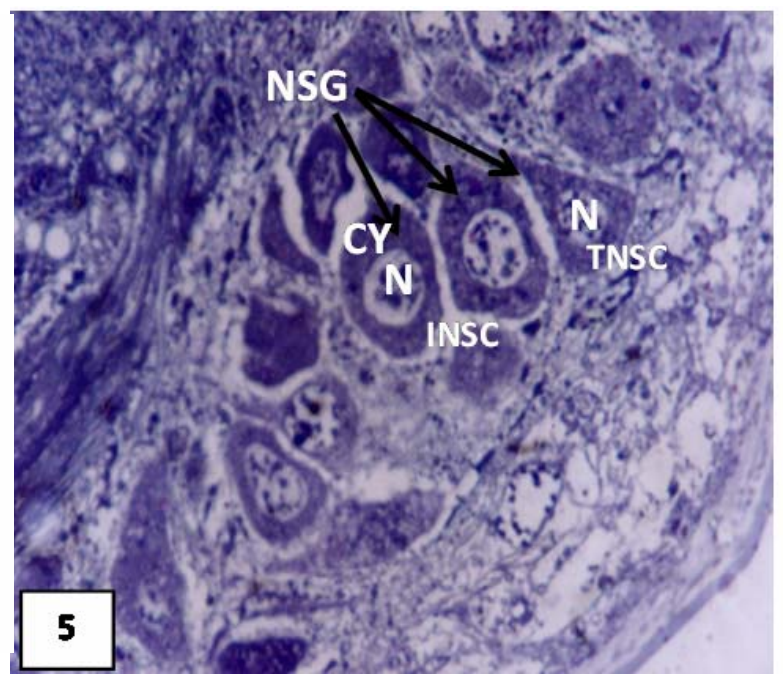

Fig. 5: Showing the structure of the irregular and triangleshaped neurosecretory cells (INSCs and TNSCs) in the posterior portion of suboesophageal ganglion (SOG). Notice the nucleus $(\mathrm{N})$ and the neurosecretory granules (NSG) in the cytoplasm (CY) . X: 400.

Figs. (2-5): Photomicrographs of semithin sections of suboesophageal ganglion (SOG) of untreated Spodoptera littoralis larvae X:200 


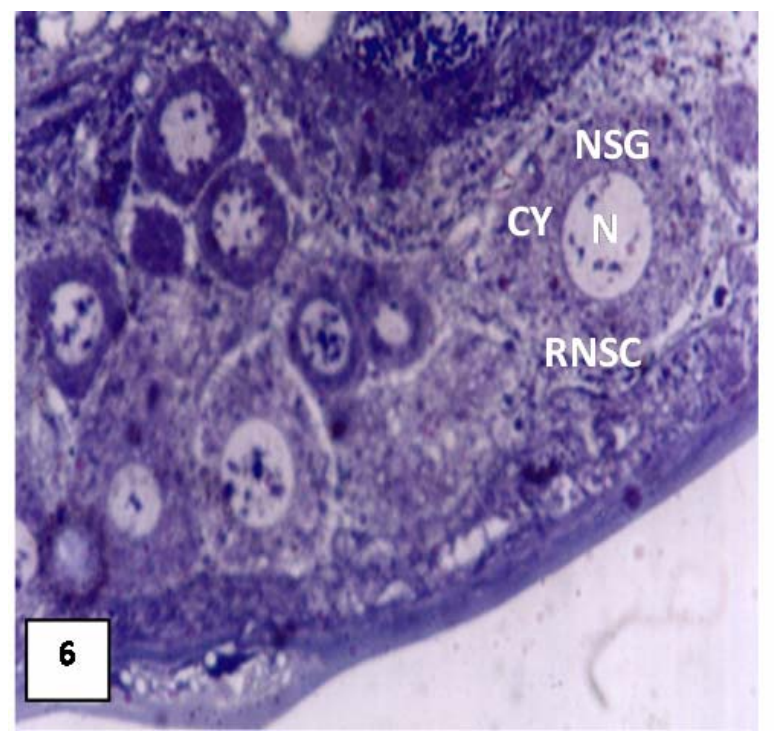

Fig.6: Showing the the nucleus $(\mathrm{N})$ and the scarcity of neurosecretory granules $(\mathrm{NSg})$ in the cytoplasm of round neurosecretory cells (RNSCs) X: 400.

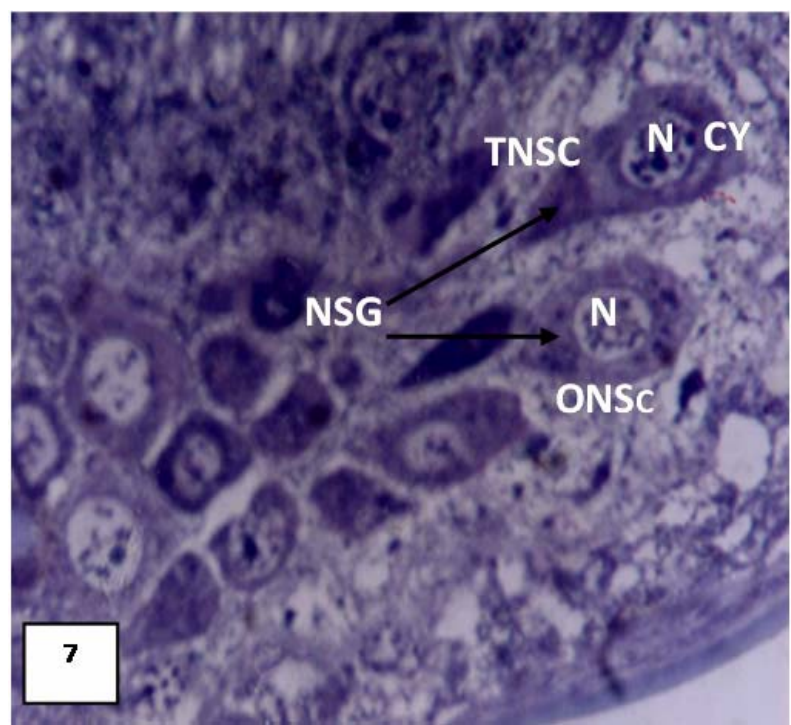

Fig.7: Showing the the nucleus $(\mathrm{N})$ and the accumulation of neurosecretory granules in the cytoplasm(CY) towards the poles of oval and triangle shaped neurosecretory cells (ONSCs and TNSCs). X:400

Figs. (6-7): Photomicrographs of semithin sections of the posterior portion of the suboesophageal ganglion (SOG) of Spodoptera littoralis larvae treated with $\mathrm{LC}_{50}$ of spinetoram.

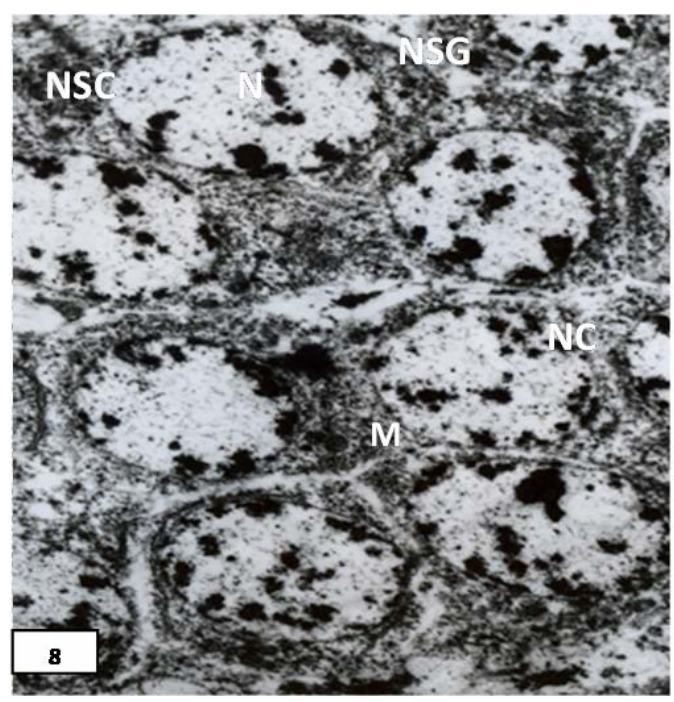

Fig.8: Electron micrograph of nerve cells (NCs) and neurosecretory cells of (SOG) of untreated Spodoptera littoralis larvae showing the nucleus $(\mathrm{N})$, mitochondria $(\mathrm{M})$ and neurosecretory granules (NSG) . X:4000

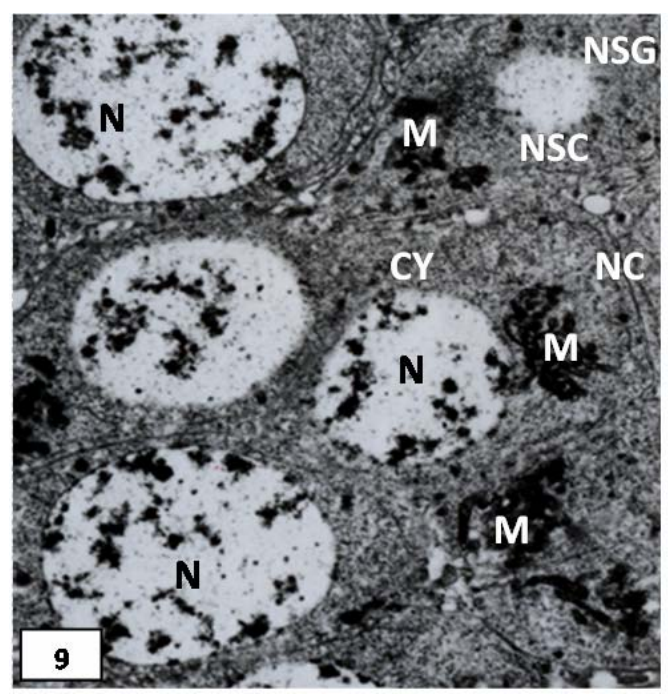

Fig.9: Electron micrograph of nerve cells (NCs) and neurosecretory cells of (SOG) of Spodoptera littoralis larvae treated with Lc ${ }_{50}$ of spinetoram showing the nucleus $(\mathrm{N})$, neurosecretory granules (NSG), increase in the size of cytoplasm (CY), abundance and aggregation of mitochondria (M) in the cytoplasm. X:4000 


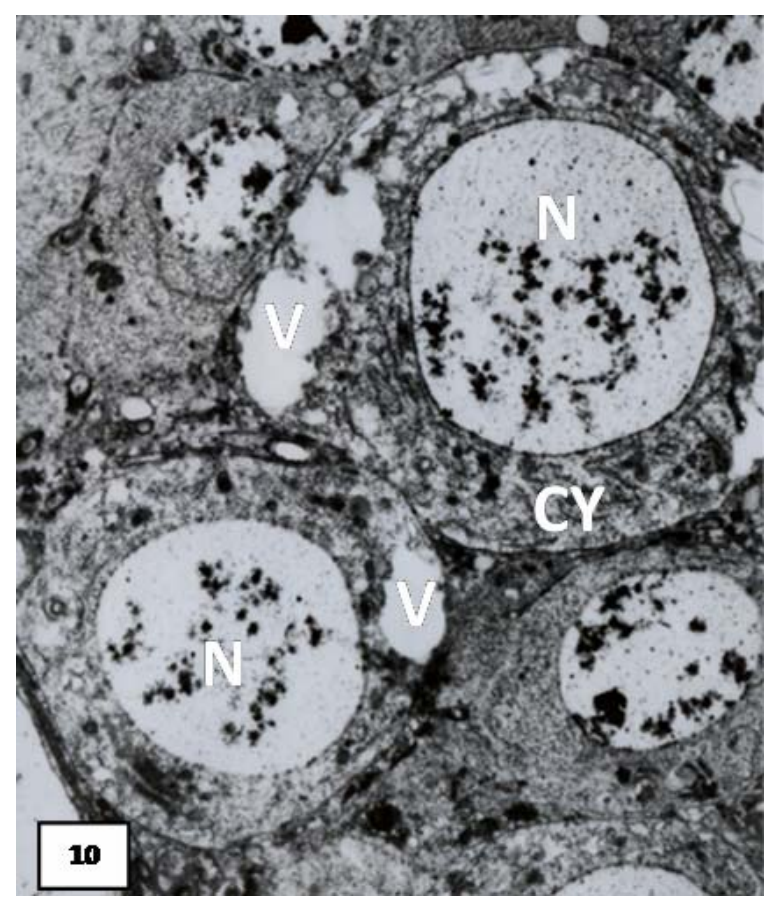

Fig.10: Electron micrograph of nerve cells ( $\mathrm{NCs}$ ) and neurosecretory cells of (SOG) of Spodoptera littoralis larvae treated with Lc 50 of spinetoram showing the nucleus $(\mathrm{N})$, vacuolization $(\mathrm{V})$ and apparent increase in the size of cytoplasm(CY). X:3000

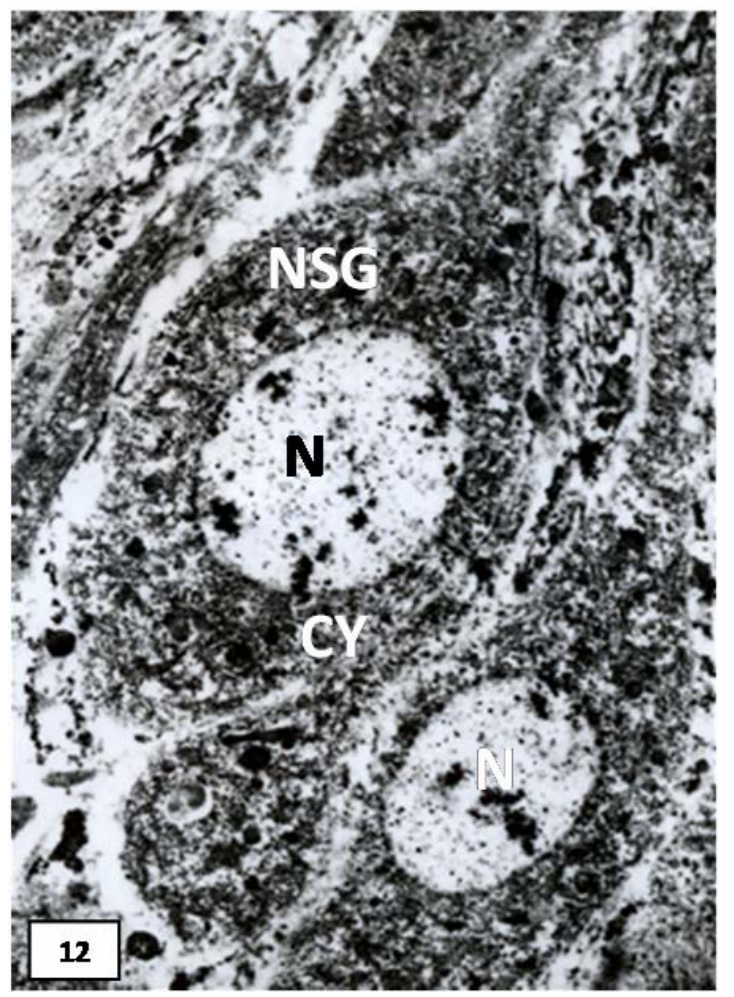

Fig.12: Electron micrograph of oval neurosecretory cells (ONSCs) of (SOG) of untreated Spodoptera littoralis larvae showing the nucleus $(\mathrm{N})$ and the neurosecretory granules (NSG) in the cytoplasm of the cells(CY). X:3000

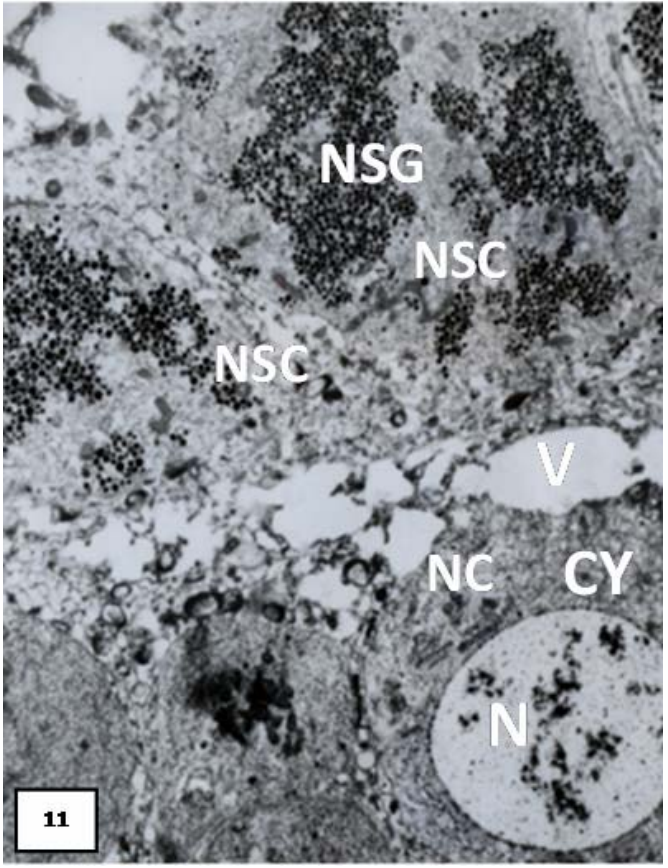

Fig.11:Electron micrograph of nerve cells (NCs) and neurosecretory cells of (SOG) of Spodoptera littoralis larvae treated with $\mathrm{Lc} 5_{0}$ of spinetoram showing the nucleus $(\mathrm{N})$, apparent increase in the size of cytoplasm $(\mathrm{CY})$, vacuolization $(\mathrm{V})$, an increase in accumulation of neurosecretory granules (NSG) in the neurosecretory cells (NSCs) and aggregation of mitochondria (M).

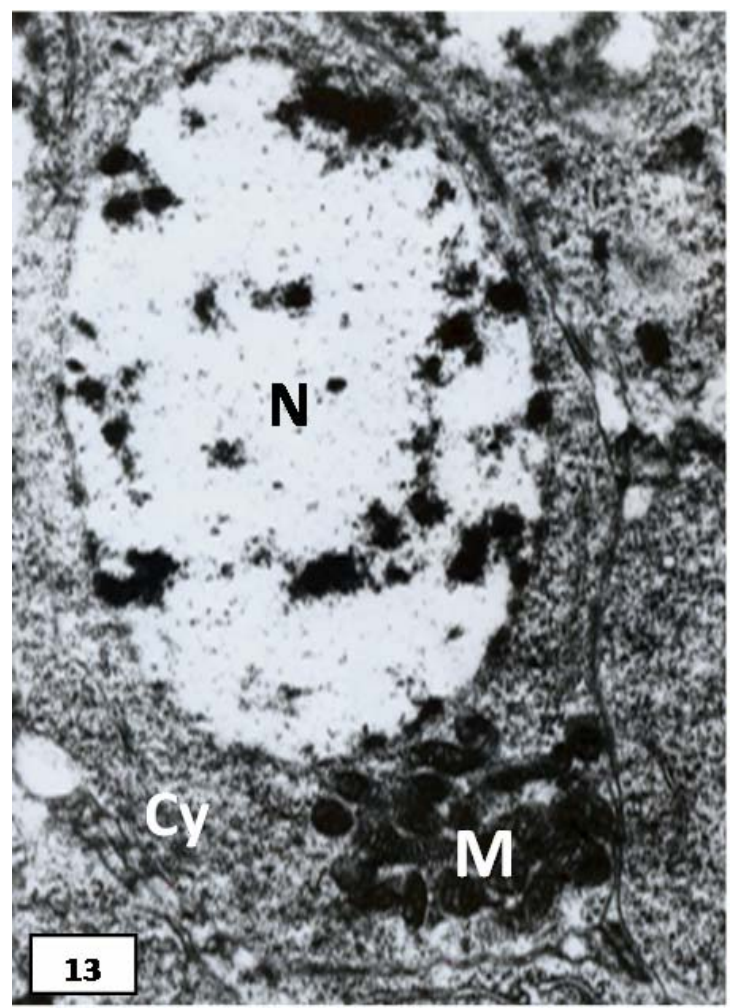

Fig.13: Electron micrograph of oval neurosecretory cells (ONSCs) of (SOG) of treated Spodoptera littoralis larvae with $\mathrm{Lc}_{50}$ of spinetoram showing the nucleus $(\mathrm{N})$ and aggregation of mitochondria $(\mathrm{M})$ in the cytoplasm of the cells $(\mathrm{CY})$. $\mathrm{X}: 10000$ 


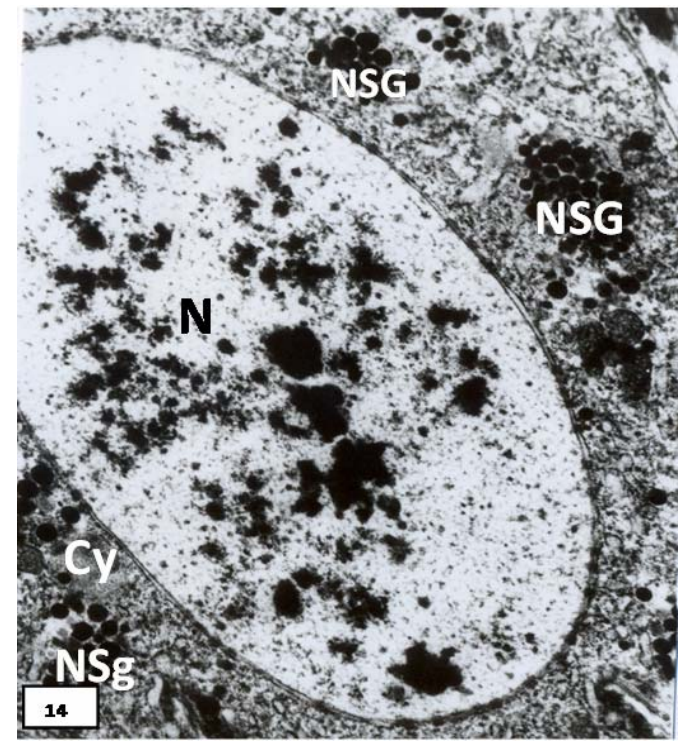

Fig.14: Electron micrograph of oval neurosecretory cells (ONSCs) of (SOG) of Spodoptera littoralis larvae treated with $\mathrm{Lc}_{50}$ of spinetoram showing the nucleus (N) and increase in accumulation of neurosecretory granules (NSG) in the cytoplasm of the cells. X:10000

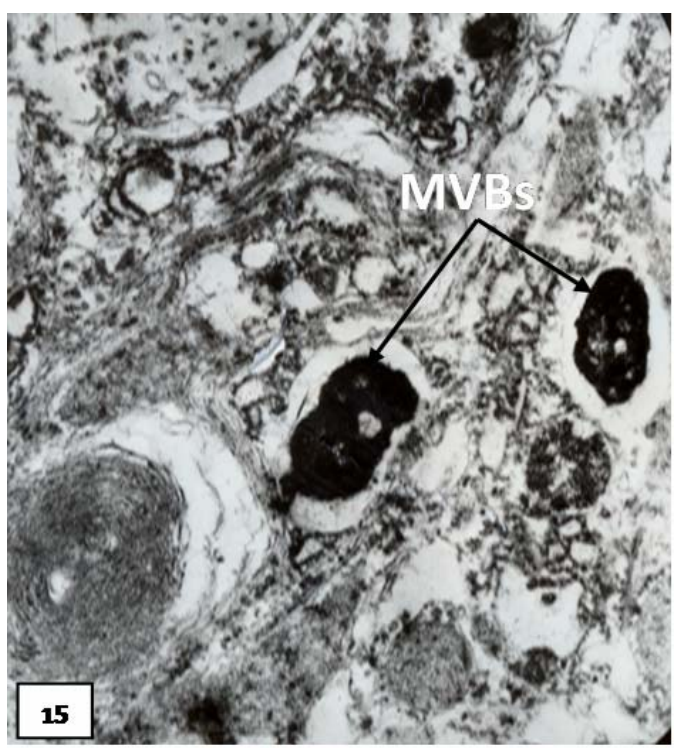

Fig.15: Electron micrograph of neurosecretory cells (NSCs) of (SOG) of Spodoptera littoralis larvae treated with $\mathrm{LC}_{50}$ of spinetoram showing the multivesicular bodies (MVBs) in the cytoplasm of the cells. X:8000 


\section{ARABIC SUMMERY}

دراسة التأثير السمي العصبي للسبينوترام (Spinetoram)

على يرقات دودة ورق القطن الكبرى سبودوبتر اليتوراليز(Spodoptera littoralis)

$$
\begin{aligned}
& \text { ليلى سيد حمودة } 1 \text { ـ حسن فرج ضاحى2 } 2
\end{aligned}
$$

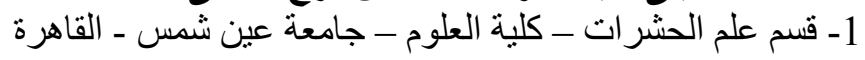

$$
\begin{aligned}
& \text { 2- معهد بحوث وقاية النبات - الدقى - الجيزة. }
\end{aligned}
$$

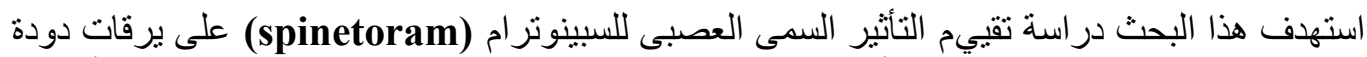

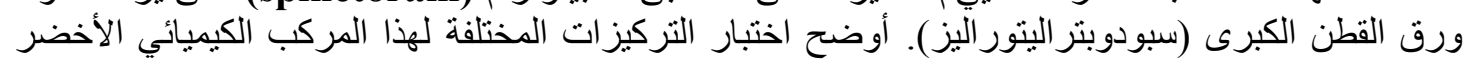

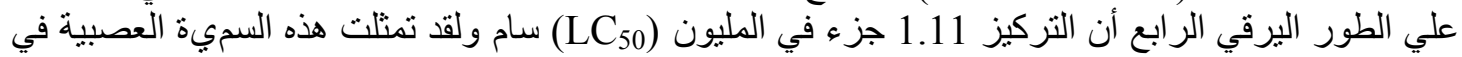

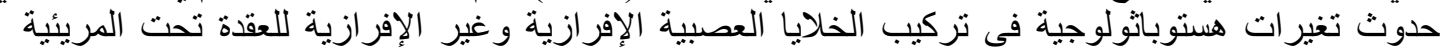

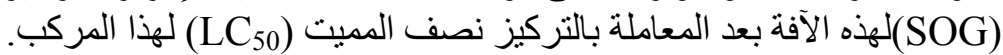

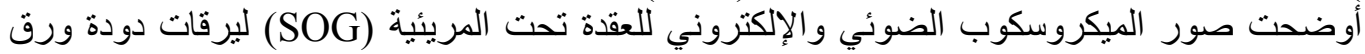

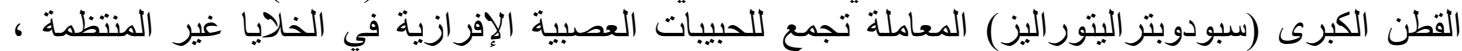

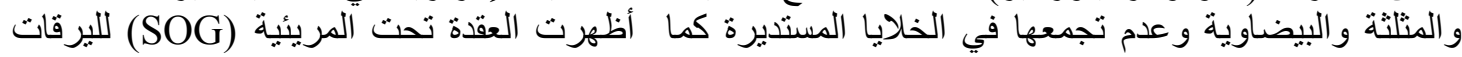

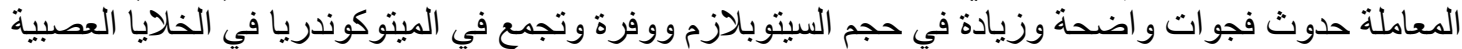

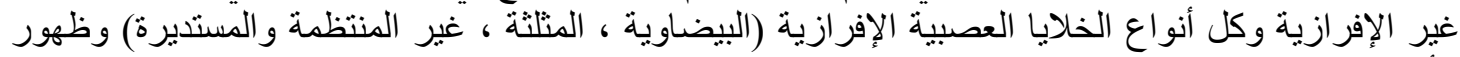
الأجسام عديدة التحوصل (MVBS) في سيتو بلازم الخلايا العصبية الإفرازية. 